\title{
SEMIOLOGICAL ASPECT OF STUDYING THE STRUCTURE AND CHRONOTOPIC FEATURES OF THE ORTHODOX LITURGICAL TEXT
}

\section{Osadcha S. V.}

\section{INTRODUCTION}

The problem of the text arises and begins to be actively discussed by the scientific community in the second half of the XX century. It is not traditional for musicology; questions of textual analysis are rather indicative of cultural studies, since many aspects of not only the artistic, but also the life process are associated with the concept of text. However, their relevance for musicologists is becoming increasingly apparent. This is confirmed by the growing interest in this problem in the publications of both domestic and foreign musicologists. These publications indicate that musicology is following the path of mastering the already accumulated scientific experience in related fields of humanitarian knowledge and is trying to develop its own methods for studying the text and its conceptual system. The theoretical basis of musical textology is developed in their works by A. Hakobyan, M. Aranovsky, N. Gerasimova-Persidskaya, Y. Gribinenko, E. Zinkevich, I. Kokhanik, V. Moskalenko, A. Samoilenko, S. Tyshko, S. Ship and some others. Among the statements of these works, two main trends can be distinguished: in some studies, the structural and compositional approach to the study of a musical text is taken as a basis in which it appears as the musical composition text; in others, attention is focused on the genre and style nature of the musical text phenomenon, on the use of various methods of stylistic interactions by composers; therefore, the significance of music as a text that goes beyond the boundaries of individual compositions and explains the intertextual features of the musical language is revealed.

This duality of the musicological approach to the text can be regarded as a reflection and continuation of the dual attitude to the text in general humanitarian disciplines.

Studying the general trends that have been developing in textology over the past decades, it can be noted that textology is more and more beginning to be regarded as a discipline that has independent and very 
large tasks. These tasks can be formulated as follows: textology aims to study the history of the text of the monument at all stages of its existence in the hands of the author and in the hands of his scribes, editors, compilers, that is, throughout the entire time that the text of the monument was changing. Only through a complete study of the history of the text of the monument as a whole, and not by episodic criticism of individual places, can the restoration of the original author's text of the monument be achieved. Textology opens up tremendous opportunities to study schools, trends, ideological movements, changes in style, the dynamics of the creative process and is an arbiter in resolving very many disputes that, outside the study of the concrete history of texts, could have stretched without prospects for their final resolution.

\section{Textology as a modern humanitarian discipline and its tasks in the field of Orthodox singing tradition}

Since the nascence of Christianity, liturgical singing, or "music of worship," has occupied a very special place in the history of world culture. This tradition develops according to special laws, in accordance with the general task of the pragmatics of worship. If the reason for the angelic singing is "an excess of grace," then the reason for the emergence of music is rooted in the loss of grace immediately following the fall of the man. After being expelled from paradise, a man who found himself in a world full of passions began to experience not only bodily hunger and illness: spiritual hunger became even more noticeable; it was caused by the loss of communication with God. The beginning of Christian church singing, as well as the beginning of Christian worship, is sanctified by the example of Christ Himself, who ended the Last Supper by singing psalms: And, having sung, they went to the Mount of Olives (Matthew 26, 30). In interpretations of the psalms, St. John Chrysostom supplements: "The Savior sang, so that we would sing in this way». At the Last Supper, the Savior himself establishes the fulfillment of the Eucharist sacrament and the need to accompany the liturgy with singing - "do this in remembrance of me" (Lk. 22, 19; 1 Cor. 11,$24 ; 1$ Cor. 11,25$)$. In most studies devoted to the study of the 
Orthodox liturgical and singing tradition, the authors agree that this moment can be called the beginning of Orthodox liturgical singing ${ }^{1}$.

Since that time, singing has become an integral part of Christian worship. The correct melodic rank, the right life, is formed by the inseparable "triple composition" (V. Martynov's term) of liturgical singing, comparable to the three-component structure of a person, consisting of body, soul and spirit. Talking about the body of liturgical singing, V. Martynov suggests to mean the singing component of the liturgy, or rather, specific melodies of liturgical chants in their totality; talking about the soul of liturgical singing, the researcher means the Charter, or Typicon, which not only organizes the life of a Christian, but also indicates the place and time of each particular melody in the mass; talking about the spirit, finally, he means an ascetic feat, «the crown of which is the acquisition of the Divine Order, or deification, and the result is a righteous order of life that generates proper singing» ${ }^{2}$. Any areas of art related to the field of liturgical singing can be correctly understood only when they are examined from the point of view of each of the three levels listed above. From this arises, according to the opinion of V. Martynov, the need for a three-stage study, analysis and description of liturgical singing.

Martynov's concept is a prerequisite for determining the specifics of textology in the field of Orthodox singing tradition insofar as it indicates its polynuclearity, multi-levelness, on the one hand, and indicates the special position of singing experience within this tradition, on the other. At the same time, Martynov is so «free» to interpret the history of liturgical singing and the cultural facts associated with it, that literally using his terminology, his approach is not possible. It becomes quite obvious that the main textual task in the field of liturgical singing is to determine the phenomenon of the liturgical text, that is, the answer to the question of what a liturgical text is and what the functional significance of its singing side is.

1 Гарднер И.А. Богослужебное пение русской православной церкви. Сущность. Система. История. Т. 1. - Сергиев Посад : Московская духовная академия, 1998; Матвеев Н. В. Хоровое пение. История русского церковного пения. - Электросталь : Издательство братства во имя святого князя Александра Невского, 1998; Мартынов В. История богослужебного пения. Учебное пособие. - М. : РИО Федеральных архивов; Русские огни, 1994.

2 Мартынов В. История богослужебного пения: учебное пособие. - М. : РИО Федеральных архивов; Русские огни, 1994. 
Based on the understanding of the text as a delimited, completed and structurally stable autonomous cultural and semantic phenomenon (according to Y. Lotman), we can assume that, being formed historically, the liturgical text is historically independent, constant structural, including spatial and temporal connections of three main levels of the Orthodox tradition: action - ordinance; pronouncing the liturgical text; finally, the musical and singing intonation of the verbal text when pronouncing it.

In other words, the liturgical text is a simultanic unity of the ritual and pragmatic, prayer and musical aspects.

The fundamental, basic level of the liturgical text is the church action, which includes objects of worship, attributes of ordinance, vestments of priests, etc., that is, the practice of ritual as a necessary component. Its direct implementation and materialization determine the structure of the verbal and musical sides, they are the strictest and obligatory; developing first of all, they are not subject to temporary changes. However, it should be remembered that the apparent immediacy of the liturgical church action is a generalization, mediation, materialization of important religious ideas.

The ritual order is a symbolic action; it bears in itself a logical religious symbolism. In this regard, the prayer level of the liturgical text explains the symbolic nature of the ritual action creates a kind of commentary on it, points to the moments of movement and pauses in worship, its internal dramaturgy, and also the processes that occur in the consciousness of those present at the Liturgy.

The text as a principle of organization and functioning of a certain system of human activity can be revealed and justified only with the involvement of historical assessments. These estimates are also necessary when characterizing the genre and style features of the text. D. Likhachev in his study "Textology" indicates that textology was mainly defined in the works of Russian researchers of the Soviet period and in the West as "a system of philological devices" for the publication of monuments and as "applied philology". For the publication of the text, only the "original", "genuine" text was important, and all other stages of the history of the text were of no interest; criticism of the text was in a hurry to jump over all stages of the history of the text to the original text to be published, and sought to develop various "methods", mechanical methods of "getting" this original text, considering all its other stages as erroneous and not authentic, not of interest to the researcher. Therefore, very often the study of the text was replaced by its "correction". The 
textologist tried to achieve a particular result, to «get» a particular text without carefully studying the entire history of the composition text as a whole" 3 .

Initially, it seemed, as D. Likhachev writes, that textology did not have such complex tasks that the relationship between texts can be solved with simple and uniform methods. It developed separately, and it seemed that the textologist was closed in solving his narrow tasks. Deepening into the tasks of publishing a text, textology, as noted above, was increasingly forced to study the history of the compositions text. It became a science about the history of the composition text, and more broadly - about the history of the text of culture. The historical approach to the text, which, among other things, makes it possible to characterize the text as a historiological category, is the main way to discover the text in its wide sense, including due to the ascent to the original samples of the text that determine its canonical properties.

Strictly speaking, the phenomenon of intertextuality cannot be characterized with sufficient completeness in a non-historical way, that is, through only abstract theoretical analysis. And finally, given that all researchers are unanimous in recognizing as the most important chronotopic functions of the text, it should be emphasized that its temporal nature should be studied not only in a composite, but also in a comparative historical way, especially when it comes to complex, integral semantic structures, to the texts of the «special kind».

In our case, this approach is necessary, since with its help it became possible to consider the Orthodox mass as a whole as a special text. The Orthodox singing tradition, which in itself can be studied as a complex textual device, is part of a more general, complexly organized textual whole. In turn, this whole, that is, the Orthodox liturgical system, can be considered as one of the subsystems of culture, and, following the thought of P. Florensky, the central, essential part of culture. Consequently, the Orthodox singing tradition is equivalent in relation to a number of signs of the functioning of culture - both as a kind of a general universal way of human existence, and as a certain historical model of human activity. In this regard, some provisions of the cultural works of Y. Lotman are very relevant for determining the communicative features of Orthodox worship.

3 Лихачев Д. С., при участии А. А. Алексеева и А. Г. Боброва. Текстология (на материале русской литературы X-XVII вв.). С-Пб.: Алетейя, 2001. С. 31-32. 
The main and initial prerequisite for Lotman is an understanding of culture as a text, and, hence, consideration of the text in the "open" space of cultural codes. It is necessary to recall that the emergence of a special kind of texts, such as "ritual", "rite", "action", according to Y. Lotman, leads to complex problems of "transcoding, equivalence, shifts in points of view, combining different "voices" in a single textual whole»". The next heuristic step, Y. Lotman calls the appearance of literary texts «polyphonic material receives additional unity, retelling in the language of this art» ${ }^{5}$.

The dynamics of literary texts has a polar orientation: on the one hand, to an increase the integrity and immanent isolation of literary texts, and on the other, to an increase in internal semiotic heterogeneity, the development of structurally contrasting subtexts in a literary text, which, in turn, can show more and more autonomy. Under these conditions, the function of the text is much more complicated and includes a number of process levels. Y. Lotman identifies five levels, namely:

1. Communication between the sender and the addressee, in which the text acts as a message sent from the information carrier to the audience.

2. Communication between the audience and cultural tradition, where the text serves as a collective cultural memory. Important qualities of this function are, as Lotman calls, on the one hand, the ability of the text to continuously replenish, and on the other hand, to actualize some aspects of the information embedded in it and almost forget others completely.

3. Communication of the addressee with himself (self-dialogue), in which the text actualizes certain aspects of the addressee personality. This text function is especially characteristic of ancient, canonical, sacred texts. During such communication of the recipient of information with himself, the text assumes the functions of a mediator, contributing to the restructuring of the personality, changing its internal selforientation and the degree of its connection with metacultural constructions.

4. Communication of the addressee with the text in which a highly organized text, showing intellectual properties, ceases to be only an

4 Лотман Ю. Семиотика культуры и понятие текста. Ю. Ломан. История и типология русской культуры. С.-Пб.: Искусство-СПБ, 2002. С. 159.

5 Лотман Ю. Семиотика культуры и понятие текста. Ю. Ломан. История и типология русской культуры. С.-Пб.: Искусство-СПБ, 2002. С. 159. 
intermediary in the communication process. The text becomes an equal interlocutor with a sufficient degree of autonomy.

5. Communication between the text and the cultural context in which the text does not act as a message, but as its full participant - the source or recipient of information. Thus, «the text, on the one hand, becoming like a cultural macrocosm, becomes more significant than it and acquires the features of a cultural model. And on the other hand, it tends to carry out independent behavior, becoming like an autonomous personality» ${ }^{6}$.

As a special case that requires special consideration, Y. Lotman singles out the procedural level of communication between the text and the metatext. On the one hand, a particular private text can fulfill the role of a describing and commenting mechanism in relation to the context; on the other hand, it, in turn, can enter into decrypting and structuring relations with some metalanguage formation. The text appears to us not as an implementation of a message in any single language, but as a complex multi-level device that stores and transmits encoded information; that is able to process and transform received messages and generate new ones. The text becomes, according to the definition of Y. Lotman, «an information generator possessing the features of an intellectual personality» ${ }^{7}$.

Thus, at a general level, it can be found that the category of culture merges with the category of text, since both of these concepts - text and culture - are addressed to the leading principles of ordering human life. Based on the definition of Y. Lotman, we can conclude that since everything that enters into the culture begins to function as a text, there are three general properties between these two categories, namely: firstly, culture and text are delimited in time and in space; that means, they have a chronotopic side, since a chronotope is always an indicator of time and place; secondly, both culture and text strive for openness and limitlessness, for overcoming borders, which can be regarded as a desire for continuation, for reproduction at a new level; thirdly, both culture and text have stable structural features, thanks to which they can be recognized and reproduced.

Considering the Orthodox liturgical and singing tradition from these positions, one should once again emphasize the special functions and

6 Лотман Ю. Семиотика культуры и понятие текста. Ю. Ломан. История и типология русской культуры. С.-Пб.: Искусство-СПБ, 2002. С. 160-161.

7 Лотман Ю. Семиотика культуры и понятие текста. Ю. Ломан. История и типология русской культуры. С.-Пб.: Искусство-СПБ, 2002. С. 162. 
significance of the canon, which appears in it in two guises - as a principle and as a form. It is in the interaction of the canon as a principle and the canon as a form that the specificity of the liturgical ritual is expressed; therefore, with all the stylistic shifts - the visible stylistic freedom of chanting - the principle dominates the form. And that is why chanting always requires following the word, the prayer text.

In other words, the form can be interpreted as a concrete implementation of the essence of the thing, or rather, one of the specific realizations. This implementation does not change the essence of the thing, but rather the content of the thing, although it adds certain properties determined by the form to it, thereby forming the third thing. The essence of the thing is the content of the form, and the form itself is independent of the content. A feature of the relationship between form and content is that content can be implemented in various forms. Submission of form to the principle - as an expression of the canonical type of thinking in the "music of worship" - can be considered as the main basis for the integrity of liturgical singing.

\section{The canonical foundations of the Charter and (Typicon) functioning as a metatext of Orthodox worship}

Textology in its narrowest sense reveals its invariant - canonical text from several versions of the text, comments on its content and produces attribution (determines whether the text belongs to a particular era and to a particular author). Hermeneutics deals with the interpretation of the text; exegetics, in turn, deals with the interpretation of sacred texts. The skill of constructing a text, its structure and composition is studied by poetics. The text can be understood also extremely broadly, as it determines the semiotics and philosophy of the text. A kind of rival of the text is reality, or, as V. Rudnev writes, "the text turns out to be everything in the world and there is no room for reality... Reality is the text written by God, and the text is the reality created by man"8.

Continuing the thought of Rudnev, we can say that, representing the reality created by man, the text is a composition; being created by God, the text becomes identical with the principles of human being at its different levels and in various functional positions. Let us clarify again: the composition produced, composed by man - the composition itself is a text in the narrow sense of the word; being created by God,

${ }^{8}$ Руднев В. Словарь культуры ХХ века. М.: Аграф, 1997. С. 307-308. 
therefore, providing a single guiding creative principle for all human actions, is a text in its broad meaning. It is important to point out that, as the first textual discipline, hermeneutics, emerging from medieval theological works, sought to understand the text in its second, broader meaning, in reliance on canonical liturgical books. It is with the second meaning and purpose of the text, which is confirmed by the history of religious culture, that its canonical functions and the appearance of the canon are associated. That is why, Orthodox worship is based on the text as the principle of construction, functioning of various, relatively independent and completed textual components of the ordering (ritual), which, in particular, explains the stability of the boundaries, (especially external) of the church action.

This stability of the external borders is provided by the canon, which Pavel Florensky calls «the condensed mind of mankind» ${ }^{9}$. From this position, the canon provides the depth and accuracy of the expression of universal spiritual need; as Florensky wrote, «The canonical is the ecclesiastical, the ecclesiastical is the catholic, and the catholic is the universal» ${ }^{10}$. The canonical is understood as created within the tradition, within the life of the canon and under its direct influence; under this condition, the random is eliminated and the true is fixed. Thus, canons in the field of church hymns, as well as in the field of ancient icon painting, were created and crystallized over the centuries, while forming a special side of the canon, which reflected the relationship between the word and the melody.

A necessary condition for understanding the essence of the canonical in the church action is, according to Florensky, involvement in it. Only in this case the phenomenon of canon and canonical in church art becomes accessible for understanding and analysis.

The thoughts of M. Bakhtin about the processes of canonization and re-accentuation are also important: "Analysis ... encounters a special kind of difficulties, determined by the speed of the two processes of transformation, which affects every linguistic phenomenon: the process of canonization and the process of re-accentuation" ". Continuing these arguments, we note that any culture, any cultural phenomenon within its own limits is equally oriented towards canonization and rearrangement.

${ }^{9}$ Флоренский П. Иконостас. Христианство и культура. М.: Аст, 2001. С. 557.

${ }_{10}^{10}$ Флоренский П. Иконостас. Христианство и культура. М.: Аст, 2001. С. 562.

11 Бахтин М. М. Слово в романе. М. Бахтин. Boпросы литературы $и$ эстетики. Исследования разных лет. С. 226. 
Without literally using the concept of the canon, M. Bakhtin calls its two types - as two poles of the text. The first pole forms a system of signs associated with everything "repeated, reproduced, repeatable and reproducible" - that which is well-known and generally understood; the second pole - everything is individual, unique - and this is "its whole meaning, its purpose, that for which it was created"12. "This is in it," writes M. Bakhtin, "which is related to truth, truth, goodness, beauty, and history"13. With respect to this pole, everything that is repeated and reproduced is material and a means. Thus, the second "anti-canonical" pole of a literary text turns out to be a different kind of canonization, which affirms the legitimacy of the author's statement and leads to a clear definition of the boundaries of the individual style.

The most authoritative researcher in the field of post-structuralist theory of text is Roland Barth, whose activities ran in various fields; in particular, Barth proved to be a brilliant literary essayist, theorist, and critic. He formulated practically all the main provisions of textology, created a whole set of key expressions and phrases, or attached the previously used terms to their post-structuralist meaning (writing, signfighting, the death of the author, the effect of reality).

As already noted, the focus of R. Barth was a type of text analysis in which the researcher shifts the focus of his scientific interests from the problem of "composition" as a whole with a stable structure to the mobility of the text as a process of "structure". "Text analysis does not set itself the goal of describing the structure of a composition; the task is not to register a certain stable structure, but rather to produce a movable structure of the text (a structure that changes throughout history), to penetrate the semantic volume of the composition into the process of meaning. Text analysis does not seek to determine what determines the text, taken as a whole as a consequence of a specific reason; the goal is rather to see how the text explodes and dissipates in the intertextual space... Our task is: to try to catch and classify (by no means pretending to strictness) not all the meanings of the text (this would be impossible,

12 Самойленко А. Культурологическая концепция диалога М. Бахтина и методологические проблемы музыкознания. Культурологічна трансформація мистецької освіти та актуальні питання творчої діяльності музиканта в сучасній Украӥні. К., 1998. С. 21-37.

13 Бахтин М. Проблема содержания, материала и формы в словесном художественном творчестве. Бахтин М.М. Литературно - критические статьи. М., 1976. С. 475. 
since the text is infinitely open to infinity: not a single reader, not a single subject, not a single science is able to stop the movement of the text), but rather, those forms, those codes through which the emergence of the meanings of the text. We will follow the paths of meaning formation. We do not set ourselves the task of finding the only meaning, not even one of the possible meanings of the text... Our goal is to conceive, imagine, and experience the plurality of the text"14.

Unfortunately, this Barth's approach, which can be called semiographic in its broad sense, was not used in musicological studies. This led to the actual identification, merging of the concepts of text and composition, and, consequently, to the unlawful simplification of the phenomenon of the text itself. Also in philological studies, Barth's ideas did not receive sufficient development; meanwhile, M. Bakhtin and D. Likhachev come very close to them in their positions.

In the study "Musical text. Structure and properties", M. Aranovsky calls the determination of the relationship between the concepts of "text" and "composition" an important task. He even engages in a polemic with adherents of the theory of synonyms of the concepts "text" and "composition", indicating that it is possible to interpret the text in its narrow sense (in the meaning of "musical notation"): "There is no doubt that the text fulfills the function of invariant with respect to the set of its variant performing implementations. But if the text is only an invariant, then this is not the whole composition, but only its specific «part», or rather, the side, which is nothing more than a sound-rhythmic structure» ${ }^{15}$. The main difference between the «text» and the «composition» Aranovsky considers as «different ways of being of the same artifact» ${ }^{16}$. In his opinion, they can be defined as two opposing views on the same phenomenon, two methodologically different approaches from each other. We can talk about the existence of a composition only if it has already taken place, if it already exists «both physically and as imagination» ${ }^{17}$. Physical existence can be defined as the ability to perceive a composition as something material - a book,

${ }^{14}$ Барт Р. Избранные работы. Семиотика. Поэтика. М.: Прогресс, 1994. С. 541.

15 Арановский М. Музыкальный текст. Структура и свойства. - М. : Композитор, 1998. С. 23.

16 Арановский М. Музыкальный текст. Структура и свойства. - М. : Композитор, 1998. С. 24.

17 Арановский М. Музыкальный текст. Структура и свойства. - М. : Композитор, 1998. С. 24. 
sheet music or disk; the existence of a composition as a representation is manifested in its perception as a kind of convoluted simultanic image of the once perceived process of sounding (M. Aranovsky). According to $\mathrm{M}$. Aranovsky, we can talk about the text as if «what is still happening is proceeding in time» ${ }^{18}$. According to $\mathrm{M}$. Aranovsky, a composition can be called what is already there, that is, real, and the text is that which is still there, or maybe, that is, possible. The composition and the text are separated by time parameters, or rather, they are at different times: the composition, being already created, is in the past, and the text, being only created, is in the present and partly in the future. "The composition unfolds as text - the text collapses as a composition» ${ }^{19}$. In this case, the composition appears as a predominantly spatial phenomenon, and the text - as primarily temporary. However, R. Barth, pointing out the difference between the composition and the text, writes that not the text is a consequence of the composition, but, on the contrary, «the composition is a train of the imaginary, stretching for the text» ${ }^{20}$. M. Aranovsky agrees with this statement, clarifying that this thesis can be considered true if we take into account the natural course of events in which the creation of the text is really preceded by the emergence of the composition as an integral phenomenon. Therefore, in this case, the distinction between the text and the composition is a consequence of the position taken by the observer. In other words, at one angle of view, what we observe is seen to be accomplished, and then it is a composition; at another, we observe the process, and then it appears as being done, and then it turns out to be a time-expanding text. M. Aranovsky proposes to call this phenomenon a projective whole, which precedes the creation of the text of the composition, but at the same time remains the ideal that the artist aspires to during the creation of the opus and which directs it as an ideal whole. Although this is not a composition, it can be called its prototype, which should unfold in the text. In the liturgical and singing tradition, this prototype, the given source for creating a single text of liturgical action, is the Typicon in combination with church tradition.

18 Арановский М. Музыкальный текст. Структура и свойства. - М. : Композитор, 1998. С. 24.

19 Арановский М. Музыкальный текст. Структура и свойства. - М. : Композитор, 1998. С. 24-25

20 Барт Р. От произведения к тексту. Ролан Барт. Избранные работы. Семиотика. Поэтика. М., 1989. С. 415. 
Thus, the text appears as that side, that aspect of the composition in which it appears in its temporal hypostasis, while the composition, in turn, is the result of the implementation of the temporal side. In other words, a text is always a process, and a composition is a consequence of a reducing and generalizing synthesis.

\section{CONCLUSIONS}

Being formed historically, the liturgical text is historically independent, constant structural, including spatial and temporal connections of three main levels of the Orthodox tradition: action ordinance; pronouncing the liturgical text; finally, the musical and singing intonation of the verbal text when pronouncing it. That is, it turns out to be simultanic unity of the ritual and pragmatic, prayer and musical aspects.

The liturgical word creates its own symbolic series, requiring special conditions of understanding. It can be considered sufficiently recognized that the word in the Orthodox ordering of passage is the focus, the central semantic element of the liturgical text. However, being sounding at its core, the Orthodox prayer text requires expression and completion in its musical side. It is the manner of musical reading (reading and singing) of the musical text is the most striking identification mark of it as a cult, religious. The singing voice of the prayer (liturgical) text forms the third, final, and, at the same time, formative level of the musical text; it is especially important that this level has been evaluated since ancient times by its emotionally expressive function, by its psychological significance. It is it that becomes not only important, but also indicative of the historical evolution of the liturgical text. The compilation of the chronology of Orthodox worship, the determination of the periodization of the history of the Orthodox tradition, as a rule, is based on the study of the evolution of the singing side of the liturgical text.

The Typicon phenomenon takes on the metatext of the Orthodox tradition, which determines the formation of genre prerequisites, genre opportunities and stylistic conditions for the development of the liturgical cycle. It allows to emphasize the special functions and significance of the Orthodox liturgical canon ${ }^{21}$, which determines the

21 Осадчая С. Явление и понятие канона как основа православной богослужебно-певческой традиции: от канонической формы к «духу творчества». Музичне мистецтво $і$ культура. Науковий вісник. Одеса: Астропринт, 2016. Вип. 22. 
formation of genre prerequisites, genre opportunities and stylistic conditions for the development of the liturgical cycle. It allows to emphasize the special functions and significance of the Orthodox liturgical canon, which appears in the singing tradition in two guises - as a principle and as a form. It is precisely in the interaction of the canon as a principle and the canon as a form that the specificity of the liturgical ritual is expressed: with all the stylistic shifts - the visible stylistic freedom of chanting - the principle dominates the form, and that is why chanting always requires following the word, the prayer text. Submission of the form to the principle, as an expression of the canonical type of thinking in music, can be considered as the main basis for the integrity of liturgical singing.

Thanks to the canon - from the side of the canon phenomenon - the interaction of the text as a principle and the text as a form in the organization of the singing material of the Orthodox worship is obvious; the expression of the complex interaction of test capabilities, genre and style conditions, canonical indicators of liturgical singing is cyclical. Cyclicity, saturated with canonicity, reflecting the nature of the text, also appears in two meanings - as a principle and as a form.

Cyclicity is a general principle of system formation in the Orthodox tradition, which determines, on the one hand, the stability of external borders, and on the other, is the main communicative property of this tradition. Fixation and streamlining of the hymnographic component functioning as the main structural component, as well as cyclicity - as a factor in the dynamics of tradition - is implemented in the Charter (Typicon), along with it - and in statutory practice, which finds its fixation in the Church Tradition.

Liturgical singing, as part of the liturgical texture itself, is strictly subject to certain rules of the Church Charter. Moreover, the statutory instructions relate not only to the order (sequence) of chant texts in the process of worship, but also to all aspects of church singing, namely: distribution of chants according to the nature of their text and melody, regulation of the breadth of melodies, speed of performance and strength (volume) of sound, personnel performers, control means, and many others. Liturgical Charter (Typicon), regulating the order of liturgical actions, readings and singing, in some cases indicates combinations of order, voices in which one or another chant needs to be performed, and also often indicates a melodic pattern for singing (similar instructions); it indicates in the most general terms the nature of the performance of famous chants or entire parts of worship. In daily worship, cyclic time 
manifests itself in a particularly structured form, since, firstly, the constant regularity of masses, their constant flow day after day, reveals the autonomy of the life of the Church, its independence from external material conditions; secondly, the liturgy itself is full of cult repetitions, which also "reproduces the circulation of the subtle world" (A. Dugin) ${ }^{22}$. Thirdly, the liturgical actions themselves performed by the clergy (this applies equally to the readable and the singing sides) are associated with movements that take on a "rotational" character.

Preserving the features of the primary genre system, the Liturgy, the typical chants included in it, and other cyclically united texts of worship having a singing form make it possible to understand that the appearance of the genre, the category of the genre, does not boil down to only artistic, especially musical purpose. In the case when the principle of functioning of the genre and the genre form express the purposefulness of the cultural tradition, taken in the unity of all its parties, the concept of the genre expands to the limits of a significant indicator, a semantic substitute for this tradition, that is, it turns out to be mostly pragmatically oriented.

Thus, the musical and singing system of Orthodox worship, considered as an independent phenomenon, accumulates and expresses its most essential and, at the same time, effective antinomy - the antinomy of the canon as a principle and the canon as a form. This antinomy is realized and peculiarly resolved in the interaction of the genre and style aspects of the singing system. The same interaction (genre and style) should be considered, as shown by the analysis of historical church experience and the current state of church Orthodox practice, based on the interaction of everyday and author's trends in church singing.

\section{SUMMARY}

The singing side of the Orthodox ordering in its semantic vocation expresses its attitude to the ongoing ritual action and the pronounced ritual text; we can say that it captures the evolutionary trends of the canonical forms of Orthodox worship (the canon as a form), while at the same time determining the limitation of these trends, that is, the limits of possible stylistic modifications.

22 Дугин А. Метафизика благой вести (православный эзотеризм). М.: Арктогея, 1995. 
The sequence and correlation of the structural layers of the Charter, which also become the main cyclic indicators, the substantive and formal circles of the Typicon, correspond to the historical sequence - the historical order of these layers appearance - circles. Thus, the significance of the historical context, including the dynamics of the historical process, in the formation of the Orthodox singing system from the side of ordinance, that is, from the action of the canon as a principle, is revealed.

However, the historical dynamics of the canonical statutory requirements can be discussed until the XI-XII centuries, when it is finalized that symbolic semiotic system of the functioning of the Orthodox Church, which becomes the genre foundation of the Orthodox singing system, takes on its final form.

Thus, the musical and singing system of Orthodox worship accumulates and expresses its most essential and, at the same time, effective antinomy - the antinomy of the canon as a principle and the canon as a form; this antinomy is realized and resolved in a peculiar way in the interaction of the genre and style aspects of the singing system. This same interaction (genre and style) should be considered, as analysis of both the historical course of church experience and the current state of church Orthodox practice shows, based on the interaction of everyday and authorial trends in church singing. The interaction of these trends forms the stylistic content of the Orthodox singing system with its leading features and characteristics, and also allows us to explain it as a musical and historical phenomenon.

\section{REFERENCES}

1. Арановский М. Музыкальный текст. Структура и свойства. М.: Композитор, 1998. 345 с.

2. Барт Р. Избранные работы. Семиотика. Поэтика. М.: Прогресс, 1994. 615 с.

3. Барт Р. От произведения к тексту. Ролан Барт. Избранные работьл. Семиотика. Поэтика. М., 1989. С. 415.

4. Бахтин М. М. Слово в романе. М. Бахтин. Bопросы литературы и эстетики. Исследования разных лет. С. 72-234.

5. Бахтин М. Проблема содержания, материала и формы в словесном художественном творчестве. М. Бахтин. Bonpocbl литературы и эстетики. Исследования разных лет. М.: Художественная литература, 1975. С. 6-72. 
6. Гарднер И.А. Богослужебное пение русской православной церкви. Сущность. Система. История. Т. 1. Сергиев Посад: Московская духовная академия, 1998. 592 с.

7. Дугин А. Метафизика благой вести (православный эзотеризм). М.: Арктогея, 1995. 264 с.

8. Лихачев Д. С. Текстология (на материале русской литературы X-XVII вв.). С-Пб.: Алетейя, 2001. 759 с.

9. Лотман Ю. Семиотика культуры и понятие текста. Ю. Ломан. История и типология русской культуры. С.-Пб.: Искусство-СПБ, 2002. C. $158-162$.

10.Мартынов В. История богослужебного пения. Учебное пособие. М.: РИО Федеральных архивов; Русские огни, 1994. 240 с.

11. Матвеев Н. В. Хоровое пение. История русского церковного пения. Электросталь: Издательство братства во имя святого князя Александра Невского, 1998. 287 с.

12.Осадчая С. Явление и понятие канона как основа православной богослужебно-певческой традиции: от канонической формы к «духу творчества». Музичне мистецтво $i$ культура. Науковий вісник. Одеса: Астропринт, 2016. Вип. 22. С. 217-225.

13.Руднев В. Словарь культуры ХХ века. М.: Аграф, 1997. 384 с.

14.Самойленко А. Культурологическая концепция диалога М. Бахтина и методологические проблемы музыкознания. Культурологічна трансформачія мистецької освіти та актуальні питання творчої діяльності музиканта в сучасній Україні. К., 1998. C. 21-37.

15.Флоренский П. Иконостас. Христианство и культура. М.: Аст, 2001. С. 521-627.

\section{Information about the author:} Osadcha S. V., Doctor of Arts, Professor at the Department of Music History and Musical Ethnograph, Odessa National A. V. Nezhdanova Academy of Music 63, Novoselskogo str., Odessa, 65023, Ukraine 